\title{
Ritual Perang Topat Sebagai Strategi Komunikasi \\ Dalam Menjaga Kebhinekaan : \\ Lessons Learnt dari Tradisi Suku Sasak dan Bali \\ Di Pulau Lombok
}

\author{
Oleh: \\ I Wayan Suadnya ${ }^{1)}$ \\ Program Studi Ilmu Komunikasi, Universitas Mataram \\ J1 Majapahit No 62 Mataram, Lombok, Nusa Tenggara Barat, Indonesia \\ Eka Putri Paramita ${ }^{2}$ \\ Program Studi Ilmu Komunikasi Universitas Mataram \\ Jl. Majapahit No 62 Mataram, Lombok, Nusa Tenggara Barat, Indonesia
}

\begin{abstract}
ABSTRAK
Indonesia negara plural dengan berbagai etnis, budaya dan agama hidup didalamnya. Agama diyakini memberikan tuntunan dan arahan dalam kehidupan manusia, tetapi terkadang agama dapat menjadi pemicu terjadinya konflik. Hal ini terjadi karena adanya pandangan monolitik yang tidak memberikan ruang untuk mengakui kebenaran agama budaya lain. Paper ini menyajikan makna ritual perang topat dan lesson learnt dari sebuah tradisi etnis sasak yang beragama Islam dan etnis Bali yang beragama Hindu.

Perang topat dapat dijadikan pelajaran yang berharga dalam mengembangkan toleransi beragama antar etnis dan budaya yang berbeda. Perang Topat mendemonstrasikan bahwa sesungguhnya etnis Sasak yang beragama Islam dan etnis Bali yang beragama Hindu dapat hidup rukun berdampingan dalam kehidupan maupun dalam melaksanakan ritual keagamannya. Komunikasi terbuka dan saling memahami antaretnis dan antaragama adalah kunci untuk menjaga kebinekaan. Dengan begitu setiap orang dalam komunitas masing-masing tidak melakukan hal-hal yang ofensif bagi umat lain. Kompromi untuk menemukan jalan tengah yang saling menguntungkan adalah hal yang harus dilakukan dalam menjaga perbedaan sebagaimana di demontrasikan dalam ritual ini. Oleh karena itu Tradisi ini terus laksanakan dan dijadikan pelajaran yang berharga dalam menjaga persatuan dan kesatuan. Nilai-nilai mulia yang terkandung didalam Perang Topat hendaknya terus digali dan diviralkan agar masyarakat dapat memahami dan menggunakannya dalam kehidupan bermasyarakat dan bernegara.
\end{abstract}

Kata kunci: perang topat, lesson learnt, pemersatu, kebinekaan.

\begin{abstract}
Indonesia is pluralist a country with multi ethnics, cultures and religions. Religion is believed to provide guidance's for humans life, however in other occasion it could become source of conflict. This happened due to monolithic belief which provides no space to accept the truth of other religions and cultures. This paper presents the meaning of ritual Perang Topat and lessons learned from the tradition of Sasak tribe who are Muslims and ethnic Bali who are Hindus
\end{abstract}

Perang Topat could be meaningful lessons learned in developing tolerance amongst different ethnics, culture and religions. It demonstrates that the Sasak ethnic and Balinese ethnic are able to live together in harmony both in daily lives and ritual ceremonies. Open communication and mutual understanding amongst ethnics is the key to sustain defferences. Therefore every one within the 
community do not provoc ofensive behaviour to other. Dialogue to find win win solutions is suggested as it it is demonstrated in the ritual. Thus this ritual need to be delivered so that it become lesson learnt in protecting unity. Values of the ritual should be explored and deseminated so that community understand and implement them.

Key words: perang topat, lesson learnt, unity and differences

\section{PENDAHULUAN}

Indonesia dan adalah negara plural dengan slogan Bhineka Tunggal Ika demikian pula halnya dengan pulau kecil yang bernama Lombok. Suatu keniscayaan bahwa berbagai suku dan agama hidup, tumbuh dan berkembang dalam wadah Negara Kesatuan Republik Indonesia (NKRI) khususnya di Pulau Lombok. Dalam kehidupan sehari-hari mereka berbaur untuk melaksanakan tugas dan kewajiban masing-masing. Mereka hidup berdampingan rukun, saling menghormati dan menghargai serta saling menolong seperti tujuan semua agama yang mengajarkan kedamaian, kebaikan untuk mencapai kebahagiaan dunia dan akhirat.

Sebagaimana kita pahami bersama, Agama memberikan tuntunan bagi kehidupan umat manusia karena agama merupakan suatu sistem kepercayaan dan norma yang meliputi perintah, larangan dan petunjuk bagi manusia dalam menjalani hidup kesehariannya dalam rangka mendapatkan kebahagiaan lahir-batin, dunia-akhirat. Oleh karena itu agama sesungguhnya dapat menjadi pemersatu dalam upaya mencapai kebahagiaan lahir dan batin. Namun menurut Geertz (1983) dalam kondisi tertentu agama bisa menyebabkan terjadinya konflik antar pemeluknya maupun antar agama.

Hal ini terbukti dengan terjadinya beberapa peristiwa konflik antar umat beragama ditanah air yang ditimbulkan oleh sikap intoleran. Sikap ini muncul karena pemahaman dan penafsiran agama yang bersifat monolitik yang cenderung memunculkan klaim kebenaran (truth claim) ada pada penafsirannya sendiri. Cara pandang ini cenderung memunculkan sikap yang tidak memberi ruang bagi pemeluk agama yang berbeda untuk mengakui kebenaran agama dan budaya lain, termasuk kearifan lokal (Sodli, 2010).

Sikap ini pada beberapa tahun terakhir dibangun semakin kuat oleh beberapa kelompok masyarakat dan dikomunikasikan secara inten, sehingga muncul sikap bermusuhan satu dengan yang lainnya dan bahkan bisa terjadi perkelahian, amuk masa hingga perang antara satu suku pemeluk agama tertentu dengan suku lainnya. Menyadari bahwa Indonesia adalah negara yang multi cultural, multi etnik dan multi agama maka merajut persaudaraan, toleransi dan kerjasama antar umat beragama adalah sesuatu yang esensial untuk dilaksanakan. Tanpa adanya persatuan, kesatuan dan kerjasama yang harmonis diantara pemeluk agama yang ada di Nusantara ini maka kebahagiaan lahir dan batin serta kesejahteraan dan keadilan sosial bagi seluruh rakyat Indonesia mustahil untuk diwujudkan bahkan NKRI mungkin sulit dipertahankan.

Pada saat yang sama, perkembangan teknologi komunikasi begitu pesatnya sehingga suatu informasi begitu cepatnya menyebar dan menjadi viral dimasyarakat. Masyarakat sudah sangat tergantung kepada teknologi informasi dan komunikasi sehingga tradisi dan kearifan 
lokal yang mempunyai nilai spiritual dan pesan moral yang tinggi dan luhur tidak lagi menjadi perhatian bahkan untuk beberapa orang mungkin bahkan dilupakan.

Paper ini menyajikan hasil wawancara mendalam dan kajian pustaka untuk mengungkap makna ritual perang topat dan lesson learnt dari sebuah tradisi etnis sasak yang beragama Islam dan etnis Bali yang beragama Hindu. Tradisi ini masih dilaksanakan oleh kedua etnis setiap tahun. Oleh pemerintah daerah ritual ini dijadikan even budaya tahunan untuk menarik wisatawan berkunjung ke Lombok. Tetapi sesungguhnya ritual perang topat berdasarkan analisis penulis mengandung nilai strategi komunikasi yang berupaya untuk memberikan ruang dan waktu untuk terjadinya komunikasi, kerjasama, toleransi, saling menghargai dan menghormati antar etnis dan agama di Pulau Lombok. Melalui paper ini diharapkan tradisi ini menjadi pelajaran dalam mempertahankan toleransi dan kerukunan umat beragama dan menjadi viral dan diresapi oleh masyarakat di Lombok dan Indonesia pada umumnya.

\section{HASIL DAN PEMBAHASAN}

\section{Asal Mula Perang Topat}

Berdasarkan hasil wawancara dengan tokoh masyarakat sasak di Kecamatan Lingsar dan sumber-sumber pustaka yang ada bahwa tradisi perang topat berawal dari cerita dimana leluhur masyarakat sasak yaitu Syekh K.H. Abdul Malik menghilang setelah menciptakan mata air. Sodli (2010) menyatakan bahwa menurut kepercayaan masyarakat setempat, pada suatu malam Bulan purnama yang hening, yang bertepatan dengan tanggal 15 bulan Qomariyah, sasih kapitu (bulan ketujuh) menurut wariga (kalender) Sasak, Syekh K.H.Abdul Malik berkhalwat semalam suntuk. Beliau baru bangun dari tempat khalwatnya esok harinya saat menjelang salat Ashar. Setelah itu beliau berjalan menuju lereng sebuah bukit yang tandus dan hanya ada satu pohon tumbuh ditempat tersebut yaitu pohon waru. Di tempat tersebut kemudian Syekh K.H. Abdul Malik berdoa dan menancapkan tongkatnya ke dalam tanah. Menurut cerita yang diperoleh, ketika tongkat diangkat maka keluarlah mata air yang sangat besar dengan suara gemuruh yang menyebabkan bunga pohon waru berguguran. Peristiwa gugurnya bunga waru ini kemudian dikenal dengan Rarak Kembang Waru.

Menurut masyarakat Lingsar, peristiwa keluarnya air akibat tancapan tongkat Syekh K.H. Abdul Malik yang menimbulkan suara gemuruh itu kemudian terciptalah nama Lingsar (lokasi mata air tempat pelaksanaan ritual perang topat). Kata "Ling" dalam bahasa Sasak berarti suara dan "sar" artinya suara atau bunyi air yang besar dan deras. Peristiwa munculnya mata air tersebut kemudian sampai saat ini diperingati setiap tahun yaitu saat bulan purnama, sasih kapitu wariga Sasak sebagai Rarak Kembang Waru atau sekarang dikenal dengan nama Perang Topat.

Pada sisi sejarah yang lain cerita didirikannya Pura Lingsar tempat perang topat dilaksanakan diketahui dimulai dari adanya perjalanan prajurit kerajaan Karang Asem ke Lombok. Menurut versi ini, bahwa Pura Gaduh dan Kemaliq Lingsar dibangun sekitar permulaan abad ke-18. Sejarah kedua Pura tersebut dibangun, dimulai dari masuknya pasukan kerajaan Karang Asem ke Lombok. Menurut cerita tokoh masyarakat Hindu di Lingsar dan Budiwanti, 
(2000); Sodli, (2010), pasukan kerajaan Karang Asem mendarat di pantai sebelah barat Pulau Lombok, lalu bergerak memasuki pedalaman pulau Lombok melalui Gunung Pengsong, Perampuan, melanjutkan perjalanan menuju Pagutan, Pegesangan, dan Gunung Sari. Dari gunung Sari pasukan kemudian bergerak ke arah timur menuju Punikan dan bermalam di tempat ini.

Pada malam hari ketika pasukan sedang beristirahat, mereka mendengar suara gemuruh, lalu keesokan harinya pasukan berangkat melanjutkan perjalanan menuju sumber suara gemuruh tersebut. Pasukan kerajaan sampai di lokasi yang sekarang dinamakan "Ulon" dan tidak jauh dari Ulon mereka kemudian menemukan sumber suara tersebut yang berupa sumber air. Menurut cerita dari tokoh yang diwawancarai dan pustaka yang dibaca (Budiwanti, 2000; Sodli, 2010) pemimpin pasukan yaitu Anak Agung Ketut (adik Raja Karang Asem) berdialog dengan pemangku adat Kemaliq yang bernama Indrawan dan berjanji akan membangun Pura Gaduh di samping Kemaliq Lingsar bila nanti sudah menguasai Pulau Lombok.

Setelah berhasil menguasai Pulau Lombok Raja kemudian memenuhi janjinya membangun Pura Gaduh sebagai tempat pemujaan etnis Bali yang beragama Hindu dan Kemaliq tempat pelaksanaan ritual etnis sasak yang beragama Islam pada tahun 1759. Letak pura tersebut berdampingan yang dimaknai sebagai penyatuan bathin dan spiritual kedua etnis secara fisik. Di tempat inilah ritual perang topat dilaksanakan (Sodli, 2010; Yuniati et al, 2015).

\section{Ritual Perang Topat}

Ritual perang topat dilaksanakan setiap tahun sekali yaitu pada pada hari ke 15 bulan ke tujuh pada penanggalan Sasak Lombok, yang disebut purnama sasih kepitu (Purnama bulan ketujuh), atau hari ke 15 bulan ke enam pada penanggalan Hindu Bali, yang disebut purnama sasih kenem (Purnama bulan keenam) (Budiwanti, 2010; Sodli, 2010).

Perang Topat adalah suatu kegiatan upacara dalam bentuk perang-perangan dan topat atau ketupat sebagai senjata yang dipakai sebagai senjata dalam perang dengan cara saling lempar dengan sesama peserta. Perang topat ini menurut tokoh adat setempat sesungguhnya dimaknai sebagai ungkapan terima kasih kepada Tuhan Yang Maha Esa atas limpahan karunianya berupa air dan kesuburan di wilayah Lingsar. Biasanya perang topat diadakan sebelum menanam padi setelah datangnya musim hujan. Masyarakat setempat juga memaknai ritual ini sebagai ekspresi untuk mengembalikan hasil yang dipanen dari sawah berupa ketupat yang kemudian diperebutkan untuk ditanam disawah masing-masing sebagai pupuk (bubus Lowong). Simbolisasi ini diyakini akan mampu mengembalikan kesuburan tanah yang mereka kelola (teori simbol). Oleh karena itu yang menjadi pemeran utama dalam kegiatan ini adalah petani atau anggota Subak Kecamatan Lingsar dan Narmada. Walaupun demikian peserta juga datang dari penjuru Lombok dari Lombok Utara, Lombok Tengah dan Lombok Timur karena keyakinan mereka akan ritual ini. 
Dalam pelaksanaanya ritual perang topat menurut Yuniati et al (2015) ada empat tahapan yang harus dilalui meliputi persiapan, pembukaan, acara inti dan penutup. Persiapan pelaksanaan ritual perang topat dilakukan bersama oleh dua suku yang mengempon Pura Gaduh dan Kemaliq. Pada saat proses persiapan komunikasi intens terjadi antara pengurus Pura Gaduh dan Kemaliq untuk membicaraan segala sesuatu yang terkait dengan teknis pelaksanaan ritual. Rapat - rapat dilaksanakan untuk mempersiapkan logistik dan semua keperluan serta pembagian tugas untuk pelaksanaan ritual. Komunikasi terjadi diinternal etnis dan antar etnis (komunikasi inter dan antar budaya terjadi dalam peristiwa ini). Peristiwa ini juga menunjukkan betapa harmoninya hubungan kedua etnis yang berbeda agama diwilayah lingsar.

Menurut tokoh adat setempat, pada zaman kerajaan dahulu dalam proses persiapan upakara dan ritual keagamaan seperti perang topat telah terjadi kesepakatan yang sangat indah dimana mereka menampilkan toleransi dan rasa saling menghargai yang begitu tinggi. Sebagai contoh dalam menentukan hewan korban. Kedua etnis bersepakat untuk tidak menggunakan hewan sapi karena hewan ini dianggap suci oleh umat Hindu dan tidak menggunakan babi karena hewan ini haram bagi umat islam. Kompromi dan jalan tengah demi keharmonisan diambil yaitu menggunakan kerbau dimana kedua etnis bisa menikmatinya (Sodli, 2010; Yuniati, 2015) Saat ini tradisi ini masih dilakukan dan mereka saling sepakat untuk membagi tugas dan melakukan semua persiapan ritual.

Tahap kedua yaitu tahapan pembukaan dimana dilakukan ritual penaek gawe. Pada prosesi ini kegiatan ritual yang dilakukan adalah upacara mendak yaitu mendak kebun odeq dan murwa daksina dalam keyakinan Hindu, dan napak tilas dalam keyakinan sasak. Pada upacara ini hewan kurban berupa kerbau diarak mengelilingi kedua pura. Nampak pada kegiatan ini kedua etnis secara bersama saling membantu satu sama lainnya. Pada ritual ini nampak bagaimana kerukunan terjalin diantara dua etnis yang berbeda agama untuk satu tujuan yang sama yaitu mengucapkan rasa syukur kepada Tuhan Yang Maha Esa dan memperingati kejadian penting yang telah dilakukan oleh leluhur mereka serta mengharapkan kedamaian dan kesejahteraan terhadap umat manusia. Menurut pemangku pura Gaduh dan Kemaliq komunikasi ritual terjadi pada prosesi ini disamping interaksi sosial yang bernilai filosofis.

Pada tahap ketiga, yaitu upacara inti yakni perang topat, komunikasi intens terjadi antara kedua etnis dimulai sejak menyembelih hewan kurban yaitu kerbau. Mereka sepakat bahwa penyembelihan hewan kurban dilaksanakan menurut ajaran islam komunitas etnis Bali menerima dengan tulus cara tersebut. Mereka bekerjasama membuat pesaji, nyerahang topat, mendak pesaji, ngaturang pesaji dan perang topat. Ritual ini dilaksanakan secara bersama dengan rasa penuh kebahagiaan dan saling tolong menolong antara kedua etnis berbeda keyakinan.

Demikian juga halnya dengan ritual yang terakhir atau yang keempat yang disebut ritual beteteh ke Sarasuta. Pada acara ini kedua etnis juga bekerjasama dan melaksanaan upacara ritual dengan penuh keharmonisan dan saling membantu satu dengan yang lainnya

Dari uraian tersebut nampak jelas bahwa komunikasi ritual yang terjadi pada proses dan rangkaian acara pelaksanaan perang topat mengisyaratkan untuk selalu terjadi komunikasi dan harmonisasi serta toleransi diantara kedua penganut agama yang berbeda. Disamping itu interaksi sosial ditampilkan sebagai ritual yang sudah tentu mempunyai makna strategis 
untuk dikomunikasikan kepada masyarakat peserta dan bukan peserta. Komunikasi yang terbuka dan toleransi yang tinggi diperlukan untuk mempersatukan dan mempertahankan kebinekaan seperti yang terjadi pada ritual perang topat.

\section{Komunikasi Ritual Perang Topat Sebagai Strategi Komunikasi Mempersatukan Kebinekaan}

Memperhatikan prosesi dari ritual perang topat dan interaksi anatara kedua etnis serta simbolisasi yang digunakan dalam ritual tersebut menunjukkan adanya tiga bentuk komunikasi yang terjadi dalam ritual perang topat yaitu komunikasi ritual, komunikasi antar pribadi dan komunikasi antar budaya. Ketiga bentuk komunikasi ini diekspresikan dalam bentuk verbal dan non verbal (Wirata, 2015; Yuniati 2015).

Dari sudut pandang ritual, pola komunikasi yang dibangun dalam ritual perang topat adalah upacara sakral (sacred ceremony)dimana setiap orang secara bersama-sama bersekutu dan berkumpul (fellowship and commonality) melakuka komunikasi dengan yang maha pencipta. Dalam pandangan Ranford (2005) pola komunikasi dalam perspektif ritual bukanlah si pengirim mengirimkan suatu pesan kepada penerima, namun sebagai upacara suci dimana setiap orang ikut mengambil bagian secara bersama dalam bersekutu dan berkumpul sebagaimana halnya melakukan upakara dalam pujawali. Dalam konsep ritual, yang lebih dipentingkan adalah kebersamaan masyarakat dalam mengekpresikan komunikasi yang dilakukan melalui doa, bernyanyi, mengarak kerbau dan seremonial lainnya.

Dalam konteks perang topat komunikasi difahami sebagai suatu proses melalui mana budaya bersama diciptakan, dilaksanakan dan ditradisikan. Komunikasi ritual perang topat diciptakan untuk dilaksanakan oleh dua etnis yang berbeda keyakinan agama untuk dilaksanakan dan ditradisikan di Lingsar Kabupaten Lombok Barat. Dan kalau dilihat dari sisi politik kekuasaan pada saat ritual ini diciptakan, diketahui bahwa sebelumnya dan pada saat itu telah terjadi penguasaan oleh etnis Bali terhadap etnis Sasak. Tentu peperangan dan perlawanan mewarnai proses penguasaan tersebut. Oleh karena itu untuk mengurangi rasa permusuhan dan menciptakan keharmonisan diantara etnis yang berkonflik maka ritual ini diciptakan untuk dilaksanakan dan ditradisikan.

Dalam konteks ini ritual perang topat dipandang sebagai upaya untuk membangun persatuan, keharmonisan dan toleransi diantara kedua etnis yang pernah bertikai. Simbolisasi penyatuan Pura Gaduh dan Kemaliq dapat dianalisis dari sudut pandang strategi komunikasi. Dalam konteks ini masyarakat penganut dua keyakinan yang berbeda disatukan dalam menjalankan ritualnya sehingga mereka bisa bersatu, bekerjasama dan saling menolong. Dalam situasi ini strategi komunikasi yang dikembangkan adalah mendekatkan kedua etnis yang pernah berseteru dan mempunyai keyakinan berbeda untuk secara fisik bisa lebih sering bertemu dan berinteraksi dalam suasana kebathinan yang suci. Hal ini bisa terjadi karena mereka yang datang ketempat pemujaan adalah mempunyai tujuan yang sama dengan hati yang bersih dan suci, sehingga dalam suasana ini mereka akan lebih mudah untuk berkomunikasi dan 
berdiskusi dalam suasana bathin yang tenang. Sebagaimana konsep komunikasi ritual bahwa sekelompok orang melakukan kegiatan sakral untuk mencapai tujuan yang suci.

Ritual ini dikemas dan diciptakan sedemikian rupa oleh para leluhur sehingga intensitas komunikasi antar etnis ini bisa terjadi lebih sering dan intensif dalam suatu prosesi keagamaan yang diyakini oleh kedua belah pihak kalau tidak dilaksanakan sebagaimana mestinya akan bisa menimbulkan masalah atau bencana. Setrategi ini dibangun sedemikian rupa sehingga tidak ada diantara keturunan mereka yang berani mengingkari tradisi tersebut. Menurut Hamad (2006) bahwa komunikasi ritual bukanlah ditujukan untuk transisi/menyampaikan pesan tetapi untuk menjaga keutuhan komunitas. Oleh karena itu kalau dipandang dari sudut yang satu ini maka tradisi perang topat adalah strategi untuk mewujudkan persatuan dan kesatuan diantara umat beragama yang ada diwilayah tersebut.

Komunikasi yang dibangun dalam tradisi perang topat juga tidak secara langsung untuk menyampaikan informasi melainkan untuk merepresentasi atau menghadirkan kembali kepercayaan-kepercayaan bersama masyarakat. Keyakinan mereka terhadap leluhur dan terima kasih mereka kepada Tuhan yang Maha Esa yang telah melimpahkan rahmatnya.

Hamad (2006) juga menjelaskan bahwa penggunaan bahasa baik melalui artifisial maupun simbolik (umumnya dalam wujud tarian, permainan, kisah, dan tutur lisan) ditujukan untuk konfirmasi, menggambarkan sesuatu yang dianggap penting oleh sebuah komunitas, dan menunjukkan sesuatu yang sedang berlangsung dan mudah pecah dalam sebuah proses sosial. Hal ini nampak jelas dari proses pemilihan hewan kurban misalnya, kedua etnis bersepakat untuk memilih kerbau untuk menghindari kemungkinan yang terjadi jika dipilih hewan kurban yang lain seperti babi dan sapi. Kedua etnis diberikan contoh bagaimana mereka harus saling menghargai dan menghormati dalam keyakinan yang berbeda sehingga tidak terjadi disharmonisasi dan intoleran.

Agar komunikator dan komunikan ikut larut dalam proses komunikasi maka pemilihan simbol komunikasi hendaknya berakar dari tradisi komunitas itu sendiri (Hamad, 2006). Dan pemilihan perang topat sebagai simbol persatuan dan toleransi didasarkan dari sejarah dan mitologi yang muncul dimasyarakat. Raja pada zamannya dengan jeli melihat hal ini sehingga ritual rarak kembang waru ditradisikan menjadi perang topat yang merupakan simbol perang kebahagiaan sebagi pengganti perang sungguhan yang sebelumnya terjadi diantara kedua etnis. Raja mengirim isyarat bahwa perang perangan dengan menggunakan topat sebagai amunisi adalah lebih membahagiakan dan mensejahterakan dibandingkan dengan perang sungguhan yang akan menelan korban jiwa dan harta benda.

Komunikasi ritual atau komunikasi ekspresif bergantung pada emosi atau perasaan dan pengertian bersama warga. Juga lebih menekankan akan kepuasan intrinsic (hakiki) dari pengirim atau penerima (Hamad, 2006). Oleh karena itu suasana kebatinan yang suci dan sakral diciptakan dalam suasana ini sehingga emosi peserta diarahkan untuk menuju suatu objek sakral yaitu penghormatan kepada jasa leluhur dan kemurahan Tuhan Yang Maha Esa. Dalam kontek ini diungkapkan bahwa ajaran agama yang dianut oleh penguasa tidak boleh 
dipaksakan kepada orang yang sudah menganut agama tertentu. Tetapi yang boleh dipaksakan adalah untuk secara bersama-sama menghormati dan mengenang jasa para leluhur dan mengucapkan pujisyukur atas limpahan rahmatNya.

\section{Lesson Learnt dari Ritual Perang Topat}

Mencermati sejarah dan prosesi perang topat serta lokasi pura tempat dilaksanakannya, kita sebagai masyarakat yang tinggal di Lombok dan Indonesia pada umumnya hendaknya mampu mengambil pelajaran dari tradisi yang di laksanakan oleh dua etnis yang pernah berseteru untuk membangun kembali persaudaraan, persahabatan, toleransi, kerjasama dan tolong menolong diantara mereka. Tradisi perang topat telah mempersatukan kembali antara dua etnis yang berkonflik. Dibangun kembali toleransi antar umat beragama. Dibangunnya gotongroyong dan kebersamaan serta persatuan serta toleransi diantara dua etnis yang berbeda keyakinan dan agama. Mereka digerakkan oleh suatu keyakinan bahwa mereka harus melaksanakan tradisi dan ritual yang diwariskan oleh nenek moyang mereka.

Makna simbolisasi dari perang topat adalah perang kemakmuran dan perang kesejahteraan dan kebahagiaan sebagai ganti dari perang sungguhan yang menyengsarakan. Dari sisi ini kita hendaknya belajar melakukan perang yang mensejahterakan ini. Keberhasilan peperangan ini adalah buah dari kebersamaan dan toleransi.

Prosesi perang topat telah mengajarkan kepada kita untuk mencapai kebahagiaan itu harus dicapai melalui kesepakatan dan komunikasi yang terbuka diantara kedua etnis. Mereka sepakat untuk tidak melaksanakan apa yang menjadi larangan bagi etnis lain dan mencari jalan kompromi untuk mendapatkan kesepakatan. Seperti yang terjadi dalam pemilihan hewan kurban.

Mereka secara sukarela saling membantu satu dengan yang lainnya dalam menyelesaikan setiap tahapan dari prosesi perang ketupat. Mereka dirajut dalam jalinan kerjasama yang mau tidak mau harus mereka lakukan karena hal ini berkenaan dengan tradisi dan ritual yang harus dilakukan. Pengorbanan atas ego dan sikap benar sendiri yang didemontrasikan pada ritual ini patut menjadi pelajaran bagi kita semua.

Kedua etnis secara bebas bisa menggunakan masing-masing tempat peribadatan ini, tetapi mereka terikat tradisi untuk menggunakan secara bersama kedua tempat peribadatan tersebut. Pada kontek ini toleransi yang sesungguhnya didemontrasikan dalam perang topat. Kita bisa belajar bahwa melalui ritual keagamaan di tempat ibadah bisa ditumbuhkan dan dikembangkan benih toleransi dan kerjasama antar umat beragama.

Dari uraian tersebut nampak jelas bahwa melalui ritual perang topat banyak pelajaran yang berharga yang dapat dipetik dan dijadikan acuan dalam mengembangkan toleransi beragama antar etnis dan budaya yang berbeda. 


\section{KESIMPULAN}

Perang topat dapat dijadikan pelajaran yang berharga dalam mengembangkan toleransi beragama antar etnis dan budaya yang berbeda. Perang topat mendemontrasikan bahwa sesungguhnya etnis Sasak yang beragama Islam dan etnis Bali yang beragama Hindu dapat hidup rukun berdampingan dalam kehidupan maupun dalam melaksanakan ritual keagamannya. Ritual perang topat merupakan strategi komunikasi raja saat itu dalam mempersatukan umat yang berselisih. Komunikasi terbuka dan saling memahami antar etnis dan antar agama adalah kunci dalam menjaga persatuan dan kesatuan. Tidak melakukan halhal yang terlarang bagi umat lain dan mencari kompromi untuk menemukan jalan tengah yang saling menguntungkan merupakan pilihan yang didemontrasikan dalam pelaksanaan ritual perang topat..

\section{SARAN/REKOMENDASI}

Tradisi ini terus dipertahankan dan dilaksanakan sehingga dapat dijadikan pelajaran yang berharga bagi warga masyarakat NTB pada umumnya. Nilai-nilai mulia yang terkadung didalamnya hendaknya terus digali dan diviralkan agar masyarakat dapat memahami dan menggunakannya dalam kehidupan bermasyarakat dan bernegara.

\section{DAFTAR PUSTAKA}

Budiwanti, Erni. 2000. Islam Sasak Wetu Telu Versus Wetu Lima. Lkis, Yogyakarta bekerjasama dengan Yayasan Adikarya

Geertz, Cliffords. 1983. Abangan, Santri, Priyayi, dalam Masyarakat Jawa, terj. Yogyakarta: Pustaka Pelajar.

Geertz, Clofford. 1992. Kebudayaan dan Agama. Yogyakarta : Kanisius.

Hamad, Ibnu. 2006. Communication as Discourse. Makalah. Jakarta: Tahun 2006.

Radford, Gary, 2005, On The Philosophy of Communication, Wadsworth, Belmont.

Rothenbuhler, Eric W, 1998, Ritual Communication: From Everyday Conversation to Mediated Ceremony, SAGE Publications, Thousand Oaks.

Sodli, A. 2010. Revitalisasi Kearifan Lokal Dalam Masyarakat Multikultural di Kecamatan Lingsar Lombok Barat.

Yuniati, K., Siti Zaenab dan I Wayan Suadnya. 2015. Komunikasi Ritual dalam Tradisi Perang Topat di Taman Lingsar Kabupaten Lombok Barat. 